\title{
AKIBAT HUKUM WANPRESTASI YANG DILAKUKAN OLEH PENERIMA WARALABA ES TEH POCI DI DENPASAR
}

\author{
Maria Cynthia Sesa Maryono, Fakultas Hukum Universitas Udayana, e-mail: \\ mcsesalaw@gmail.com \\ I Wayan Novy Purwanto, Fakultas Hukum Universitas Udayana, e-mail: \\ novypurwanto17@gmail.com
}

doi: https://doi.org/10.24843/KS.2020.v08.i11.p02

\begin{abstract}
ABSTRAK
Tujuan Penulisan dari karya ilmiah ini untuk mengetahui bentuk perjanjian serta akibat hukum bagi pihak penerima waralaba jika melanggar perjanjian waralaba Es Teh Poci dikota Denpasar. Jenis penelitian yang digunakan dalam penulisan artikel ini adalah jenis penelitian hukum empiris. Teknik pengumpulan data yang digunakan dalam penulisan ini adalah dengan cara wawancara dan dilakukan pada orang - orang yang terlibat dalam praktik perjanjian waralaba Es Teh Poci. Hasil studi menunjukkan bahwa bentuk perjanjian waralaba Es Teh Poci dikota Denpasar Selatan merupakan bentuk perjanjian dibawah tangan, pada perjanjian ini mengatur ketentuan yang berlaku dalam menjalankan waralaba Es Teh Poci tetap dapat berjalan dengan baik didalam sistem hukum maupun segi penjualannya. Akibat yang terjadi apabila pihak penerima waralaba melakukan wanprestasi didalam suatu perjanjian waralaba Es Teh Poci di Kota Denpasar Selatan menjelaskan apabila pihak mitra melanggar ketentuan yang berlaku dari segi hak dan kewajiban, maka perjanjian yang telah disepakati dapat berakhir. Pihak pemberi waralaba akan membatalkan perjanjian kerjasama dan meminta pihak penerima waralaba untuk menghentikan penjualan produk pihak pemberi waralaba.
\end{abstract}

Kata kunci: Waralaba, Perjanjian, Wanprestasi

\begin{abstract}
The purpose of writing this scientific paper is to find out the form of the agreement and the legal consequences for the franchisee if it violates the Es Teh Poci franchise agreement in the city of Denpasar. This type of research used in writing this article is a type of empirical legal research. The data collection technique used in this writing is by means of interviews and is carried out on people who are involved in the practice of the Es Teh Poci franchise agreement. The form of the Es Teh Poci franchise agreement in the city of South Denpasar is a form of under-hand agreement, in this agreement the provisions that apply in running the Es Teh Poci franchise can still run well in the legal system and in terms of sales. The consequences that occur if the franchisee defaults in an Es Teh Poci franchise agreement in South Denpasar City explains that if the partner violates the applicable provisions in terms of rights and obligations, the agreement that has been agreed can end. The franchisor will cancel the cooperation agreement and ask the franchisor to stop selling the products of the franchisor.
\end{abstract}

Keywords: Franchise, Agreement, Default

\section{Pendahuluan}

1.1. Latar Belakang Masalah

Sejalan dengan perkembangan ekonomi di negara ini, Indonesia menjadi satu dari sekian banyak negara negara yang memiliki banyak hubungan bisnis dengan 
negara lainnya di seluruh dunia. Usaha yang banyak ditemui dan dikembangan di Indonesia adalah usaha waralaba. Waralaba atau franchise adalah hubungan usaha atau bisnis antara pemilik merek, dengan pihak lain yang berupa mengizinkan dari pemakaian merek dalam waktu yang sudah ditentukan.

Waralaba adalah suatu cara untuk melaksanakan bisnis, untuk memasarkan jasa atau produk ke masyarakat. Waralaba dapat artikan sebagai suatu cara memasarkan jasa dan barang, dimana sebuah perusahaan memberikan kepada perusahaan lain, hak khusus untuk menjalankan suatu bisnis dengan ketentuan yang sudah di tetapkan. Pembangunan ekonomi nasional didalamnya struktur ekonomi yang ada di Indonesia di penuhi dengan pengusaha yang tergabung dalam usaha kecil, usaha menengah dan usaha besar, dan waralaba termasuk di dalamnya. ${ }^{1}$

Waralaba merupakan bisnis yang sangat menjanjikan. Dalam perekonomian Indonesia sangat cocok untuk melakukan bisnis waralaba karena bisnis waralaba memiliki kegagalan yang kecil dan memiliki pertumbuhannya yang sangat pesat. Semakin meningkatnya bisnis atau usaha waralaba sebagai suatu sistem distribusi atau pemasaran jasa dan barang menjadikan bisnis waralaba tersebut populer. Karena efektifnya sistem pemasaran melalui sistem waralaba keberadaannya pun dianggap mampu memasarkan suatu bentuk produk keseluruh Indonesia. Karena bisnis atau usaha waralaba ini menjanjikan dalam kata lain berpeluang besar di Indonesia menyebabkan waralaba asing dan juga waralaba lokal mulai bertambah dan meningkat dengan sangat pesat. Untuk memulai bisnis bagi seorang pemula bentuk usaha dengan sistem ciri khas usaha ini sangat cocok untuk memulai usaha yang baru.

Bisnis yang berkembang saat ini perlu dilindungi paying hukum untuk melindungi masyarakat didunia bisnis tidak terkecuali bisnis waralaba. Hal ini berguna untuk melindungi pihak - pihak dalam bisnis waralaba. Keberadaan hukum dalam bisnis mempunyai tujuan memberi kepastian hukum dan menciptakan rasa keadilan dalam hidup masyarakat, sehingga ada pertanggungjawaban bila terjadi dampak yang muncul dari bisnis tersebut. Untuk menanggulangi sesuatu hal yang tidak diinginkan oleh orang - orang atau pun pebisnis yang mau masuk didalam dunia bisnis lebih baik memahami terlebih dahulu hukum bisnis seperti apa yang akan dijalankan untuk menciptakan manfaat bagi masyarakat umum dalam hal mensejahterakan dan juga memberikan manfaat bagi diri atau individu agar usaha yang dijalankan berjalan sebagaimana mestinya dengan baik.

Dalam bisnis waralaba dibutuhkan adanya suatu perjanjian. Perjanjian waralaba adalah suatu bentuk perlindungan hukum dari para pihak yang melakukan hal yang dilarang atau membuat rugi pihak yang ada. Bila terjadi suatu pelanggaran dalam perjanjian waralaba, pihak yang dirugikan bisa melakukan penuntutan terhadap pihak yang melakukan pelanggaran dengan hukum yang berlaku saat ini. Perjanjian tersebut tidak hanya diperlukan untuk perjanjian waralaba berskala internasional, namun juga berlaku untuk bisnis waralaba berskala nasional. Salah satu waralaba yang beroperasi di Denpasar adalah Es Teh Poci. Es Teh Poci adalah bisnis waralaba yang bergerak pada industri minuman dimana produk utama adalah es tes.

\subsection{Rumusan Masalah}

Berdasarkan pada latar belakang masalah yang ada diatas maka dapat dirumuskan permasalahan sebagai berikut ini:

1 Maharatih, Ni Wayan, "Studi Kritis Pengenaan Pajak Penghasilan Final Bagi Usaha Mikro Kecil Menegah." Jurnal Magister Hukum Udayana, vol. 8, no. 1 (2019): 2 
1. Bagaimanakah bentuk perjanjian waralaba Es Teh Poci yang ada di Kota Denpasar?

2. Apakah akibat hukum bagi pihak Penerima Waralaba jika melanggar perjanjian waralaba Es Teh Poci Di Kota Denpasar?

\subsection{Tujuan Penulisan}

Tujuan penelitian untuk mengetahui bentuk perjanjian waralaba Es Teh Poci dikota Denpasar dan akibat hukum apabila terlah terjadi wanprestasi pada perjanjian waralaba Es Teh Poci dikota Denpasar.

\section{Metode Penelitian}

Dalam penulisan artikel ini mempergunakan metode penelitian hukum empiris. Pada penelitian ini melihat hukum sebagai fenomena sosial (berbeda dengan penelitian hukum normatif yang melihat hukum sebagai norma positif pada sistem perundangan hukum nasional) menggunakan pendekatan kuantitatif dan structural. ${ }^{2}$ Dalam penulisan ini menggunakan pendekatan yuridis empiris, yang adalah dilakukan dengan membaca buku-buku serta literatur perundang - undangan dengan dikaitkan dengan permasalahan yang ada masyarakat dalam kaitannya dengan Akibat Hukum Bagi Pihak Penerima Waralaba Jika Melanggar Perjanjian Waralaba Es Teh Poci di Kota Denpasar. Teknik analisis yang dilakukan dengan bahan hukum sekunder dan primer. Lalu dari data yang terkumpulkan diolah dengan cara menyusun data data secara sistematis sehingga diperoleh gambaran secara utuh untuk memudahkan dalam mengambil suatu kesimpulan.

\section{Hasil dan Pembahasan}

\subsection{Bentuk Perjanjian Waralaba Es Teh Poci yang ada di Kota Denpasar}

Waralaba adalah sebuah cara dalam melakukan usaha, yakni cara untuk memasarkan jasa atau produk kepada masyarakat luas. Dikatakan pula waralaba dikatakan sebagai sebuah sistem dalam memasarkan atau mendistribusikan jasa atau barang. Yang mana pihak pemberi waralaba sebagai induk perusahaan memberikan kepada penerima waralaba yaitu usaha menengah berskala kecil hak yang di gunakan secara istimewa sesuai dengan kesepakatan yang sudah di tentukan. Sebuah perjanjian di dalamnya terdapat kewajiban dan hak pihak - pihak yang ada didalamnya. Perjanjian adalah sumber yang menjadikan perikatan, bertujuan untuk mencapai kepastian hukum di dalamnya. ${ }^{3}$

Waralaba adalah hak khusus yang diterima dari pemberi waralaba yang telah diberikan pada penerima waralaba dengan kewajiban untuk menjual produk baik jasa atau barang dari pemberi waralaba, sesuai dengan perjanjian waralaba. ${ }^{4}$ Waralaba merupakan salah satu cara melaksanakan pekerjaan bersama pada usaha antara dua perusahaan yang mana salah satu pihak sebagai penerima dan pihak lain sebagai pemberi waralaba yang mana di dalamnya telah diatur agar para pihak terlibat sebagai

2 Amirrudin, dan Asikin, Zainal, Pengantar Metode Penelitian Hukum (Jakarta, Grafindo Persada, 2012), 167.

3 Prasnowo, Aryo dan Badriah, Siti Malikhatun, "Implementasi Asas Keseimbangan Bagi Para Pihak Dalam Perjanjian Baku." Jurnal Magister Hukum Udayana, vol. 8, no. 1 (2019): 2

4 Wisanjaya, I Gede Pasek Eka, "Tinjauan Yuridis Terhadap Klausula Dalam Perjanjian Waralaba Yang Dapat Menimbulkan Praktek Monopoli." Jurnal Kertha Semaya, vol. 2, no. 6 (2014): 2 
orang yang memiliki sebuah usaha yang telah memberikan hak kepada penerima waralaba untuk melakukan kegiatan usaha dari sebuah produk jasa atau barang dan akan ada imbalan yang di bayarkan kepada pemberi waralaba. Perjanjian waralaba secara umum dapat dikatakan sebagai bentuk kesepakatan yang diputuskan bersama oleh penerima dan pemberi waralaba dalam bentuk perjanjian tertulis. ${ }^{5}$

Bentuk kontrak terdapat dua macam, yang pertama perjanjian secara lisan, dan yang kedua perjanjian secara tertulis. Perjanjian secara tertulis merupakan perjanjian yang dilakukan oleh pihak - pihak dan di buat dalam bentuk tulisan, sedangkan perjanjian lisan adalah perjanjian yang dilakukan oleh para pihak secara lisan.

Dalam perjanjian waralaba, dapat terjadinya wanprestasi yang akan menimbulkan kerugian bagi pihak lainnya dan tidak mencapai tujuan dari perjanjian tersebut. Suatu kelompok dikatakan efektif sejauh mana dapat mencapai pada tujuannya. Hukum bisa dikatakan efektif apabila ada dampak dari hukum yang positif, maka saat itulah hukum dikatakan mencapai tujuan dengan merubah ataupun membimbing sikap perilaku yang dimiliki manusia sehingga dapat menjadi perilaku hukum. Dengan adanya efektivitas dalam hukum, maka hukum tidak hanya mengandung unsur memaksa eksternal tapi juga dengan proses di pengadilan. Ancaman paksaan merupakan salah satu unsur dalam suatu peraturan dalam hal ini sebuah perjanjian agar para pihak di dalaamnya menjadi taat terhadap peraturan tersebut. 6

Pada Pasal 4 ayat (1) Peraturan Pemerintah Nomor 42 Tahun 2007 tentang Waralaba, menetapkan waralaba dilaksanakan didasarkan pada perjanjian yang tertulis antara penerima waralaba dan pemberi waralaba dan memerhatikan hukum yang ada di Indonesia. Berdasarkan ketentuan ini sangat jelas dimengerti, bila penerima dan pemberi waralaba telah mencapai kata sepakat maka dengan ini perjanjian waralaba wajib dibuat dalam perjanjian yang tertulis. Berikut bentuk perjanjian tertulis, di antaranya: ${ }^{7}$

1. Perjanjian di bawah tangan dimana perjanjian tersebut hanya ditanda tangani oleh pihak yang terlibat dalam perjanjian itu. Perjanjian ini hanya dapat mengikat pihak yang ada pada perjanjian ini, akan tetapi perjanjian ini tidak dapat mengikat pihak lain yang dapat disebut sebagai pihak ketiga. Dapat dikatakan, apabila pihak ketiga menyangkal perjanjian tersebut, maka pihak yang terlibat didalam perjanjian tersebut wajib untuk memberikan pembuktian keberatan dari pihak ketiga dengan maksud tidak bisa dibenarkan.

2. Perjanjian dihadapan notaris yang menjadi saksi dan untuk melegalisir tanda tangan para pihak yang bersangkutan. Kegunaan dari notaris sebagai saksi hanya untuk membenarkan suatu dokumen yang telah dilegalkan tentang kebenarannya sebuah perjanjian yang dibuat oleh pihak yang bersangkutan. Tetapi, kesaksian dari notaris itu tidak dapat memengaruhi kekuatan hukum pada isi perjanjian. Mungkin saja ada pihak menyangkal isi

5 Prawira, I Kadek Bagus Indra Dwi, "Perlindungan Hukum Terhadap Penerima Waralaba Dalam Perjanjian Waralaba ACK Fried Chiken di Denpasar." Jurnal Kertha Semaya, vol.3, no. 2 (2015): 6

6 Paryani, Luh Suni Muci, "Wanprestasi Dalam Pelaksanaan Perjanjian Waralaba Pada Lembaga Bimbingan Belajar Di Kota Denpasar." Jurnal Kertha Semaya, vol. 3, no. 2 (2015): 4

7 HS, Salim, Hukum Perjanjian Teori dan Praktik Penyusunan Perjanjian (Jakarta, Sinar Grafika, 2008) hal. 42 
dari perjanjian, akan tetapi para pihak tersebut yang menyangkal itu merupakan pihak dimana dia harus membuktikan apa yang disangkalnya.

3. Perjanjian berbentuk akta notariil, yang mana akta tersebut dibuat dan juga disahkan oleh notaris. Akta notariil merupakan akta otentik dimana akta tersebut dibuat oleh pejabat yang berwenang untuk membuatnya. Pejabat yang memiliki wewenang dalam membuat akta ini adalah PPAT, notaris, dan yang lain - lain. Jenis perjanjian tersebut adalah alat yang digunakan sebagai bukti yang sangat sempurna di mata hukum dan juga bagi para pihak yang bersangkutan.

Kesepakatan diantara para pihak pihak yang terlibat di dalam perjanjian merupakan suatu syarat yang harus terpenuhi apabila syarat tersebut terpenuhi maka perjanjian tersebut dapat dikatakan sah dimata hukum serta dapat mengikat para pihak di dalamnya. ${ }^{8}$

Perjanjian waralaba di dalamnya terdapat ketentuan, persyaratan, dan komitmen yang sengaja di buat oleh para pihak di dalamnya, hal ini dilakukan untuk mendapat perlindungan hukum dalam menjalankan usaha waralaba ini. ${ }^{9}$

Sedangkan bentuk perjanjian tidak tertulis adalah suatu perjanjian yang dibuat oleh pihak - pihak dalam wujud lisan. Perjanjian lisan adalah sebuah perjanjian yang telah disetujui kedua belah pihak secara lisan. Berbeda dengan perjanjian tertulis, perjanjian lisan tidak menjelaskan secara detail mengenai ketentuan dan hal - hal yang telah disetujui dalam sebuah dokumen. Berdasarkan uraian di atas maka dapat disimpulkan bahwa bentuk perjanjian waralaba Es Teh Poci yang ada di kota Denpasar merupakan bentuk perjanjian waralaba dibawah tangan, Perjanjian di bawah tangan merupakan bentuk perjanjian yang telah dibuat oleh pihak - pihak yang terlibat di dalamnya tanpa ada campur tangan pejabat yang memiliki wewenang membuatnya dan peraturan perundangan tidak mengatur secara jelas formatnya.

\subsection{Akibat Hukum Bagi Pihak Penerima Waralaba Jika Melanggar Perjanjian Waralaba Es Teh Poci Yang Ada di Kota Denpasar}

Dalam perjanjian waralaba syarat utama yang harus dipenuhi ialah adanya subjek dan objek. ${ }^{10}$ Syarat berkaitan dengan subyek yang membuat perjanjian, sementara obyektif karena berkaitan dengan obyek dalam perjanjian. Perjanjian bisa batal bila syarat subyektif tidak terpenuhi, hal ini dapat dilakukan atas permintaan pihak terkait dan dilakukan oleh hakim. Pembatalan perjanjian ini memiliki batas waktu lima tahun. Dalam kontrak usaha waralaba harus terdapat kewajiban dan hak pihak - pihak dalam usaha waralaba, serta kewajiban dan hak itu di tuliskan dalam bentuki perjanjian. ${ }^{11}$

8 Aliyah, Habibatul, "Analisis dari Segi Hukum Terhadap Perjanjian Kemitraan Antara Usaha Mikro, Kecil, dan Menengah dengan Usaha Besar." Jurnal Kertha Semaya, vol. 7, no. 3 (2019): 9

9 Trisnadewi, Ida Ayu, "Kedudukan Hukum Para Pihak Dalam PErjanjian Waralaba Di Indonesia." Jurnal Kertha Semaya, vol. 2, no. 2 (2014): 4

10 Angelita, Zhanniza Elrian, "Syarat - Syarat Pembentukan Perjanjian Waralaba Berdasarkan Peraturan Pemerintah Nomor 42 Tahun 2007 Tentang Waralaba." Jurnal Kertha Semaya, vol. 3, no. 1 (2015): 3

11 Dewi, Putu Eka Trisna, "Implementasi Ketentuan Restrukturisasi Kredit Terhadap Debitur Wanprestasi Pada Kredit Perbankan." Jurnal Magister Hukum Udayana, vol. 4, no. 2 (2015): 245 
Adapun upaya yang dilakukan apabila pihak dalam bisnis waralaba melakukan wanprestasi. Untuk melindungi pihak dalam bisnis waralaba maka diperlukannya kepastian hukum. Asas kepastian hukum merupakan asas yang menjadikan keadilan, kepatuhan, sebagai hal utama dalam setiap kebijakan yang di buat negara. Asas pacta sunt servanda yang merupakan nama lain dari asas kepastian hukum, adalah asas yang erat hubungannya dengan akibat dari suatu perjanjian. Sehingga dalam menyelesaikan permasalahan wanprestsi dalam bisnis waralaba ialah kembali kepada sanksi dalam perjanjian yang mereka buat. ${ }^{12}$

Pada sebuah perjanjian waralaba, jika terdapat wanprestasi akan terjadi akibat hukum, dimana perjanjian dapat dibatalkan secara sepihak. ${ }^{13}$ Wanprestasi adalah tidak terpenuhinya prestasi pada hukum perjanjian di kenal sebagai doktrin, arti doktrin adalah memenuhi prestasi. Jika para pihak tidak melakukan prestasinya dengan substansial maka pihak tersebut disebut tidak melakukan perjanjian secara materiil. Suatu perbuatan dikatakan wanprestasi adalah perbuatan yang tentunya ingin dihindari oleh semua pihak yang melakukan perjanjian karena dengan begitu akan mengurangi permasalahan yang timbul dan menghindari sengketa juga diantara para pihak.Dapat dikatakan bahwa wanprestasi terjadi karena adanya perjanjian itu sendiri, dimana terdapat hak dan kewajiban para pihak untuk dipenuhi. ${ }^{14}$

Adapun bentuk pelanggaran yang terdapat didalam Perjanjian waralaba dapat diketahui dari Pihak Pertama atau pihak yang memberi waralaba atau juga dari Pihak kedua atau pihak yang menerima waralaba adalah sebagai berikut:

Pihak Pertama selaku pemberi waralaba harus menjalankan segala kewajiban didalam pelaksanaan perjanjian yang berlaku, adapun pelanggaran yang dapat dilakukan pihak pertama adalah tidak memberikan hak kepada pihak kedua sebagaimana dijelaskan didalam perjanjian Es Teh Poci.

Pada Perjanjian Waralaba Es Teh Poci di Kota Denpasar di katakan bahwa Pihak Pertama berhak melakukan pemeriksaan, pengawasan kepada Pihak Kedua (Mitra) untuk memastikan di laksanakannya kewajiban - kewajiban Mitra berdasarkan Perjanjian tersebut. Apabila menurut penilaian Pihak Pertama, Mitra tidak melaksanakan kewajibannya berdasarkan Perjanjian, maka Pihak Pertama akan memberikan peringatan tertulis dan Mitra berkewajiban untuk memperbaiki dalam jangka waktu yang ditentukan dalam peringatan tersebut. Apabila Mitra tetap tidak dapat memperbaiki dalam waktu yang sewajarnya menurut penilaian Pihak Pertama, maka dengan melepaskan ketentuan pasal 1266 dan pasal 1267 Kitab Undang-Undang Hukum Perdata Pihak Pertama akan membatalkan Perjanjian tersebut dan meminta Mitra untuk menghentikan penjualan Produk kepada konsumen serta pelanggan serta Mitra tidak akan mendapatkan kompensasi dalam bentuk apa pun dari Pihak Pertama. Dalam perjanjian waralaba terdapat kewajiban serta hak dari para pihak. ${ }^{15}$

12 https://www.scribd.com/doc/46240963/Asas-Kepastian-Hukum, diaskses pada 3 September 2018

13 Handayani, Gusti Ayu Mirah, "Pelaksanaan Perjanjian Waralaba (Francise) Kuch2hotahu Di Denpasar." Jurnal Kertha Semaya, vol. 4, no. 3 (2016): 4

14 Kurniawan, Nyoman Samuel, "Konsep Wanprestasi dalam Hukum Perjanjian dan Konsep Utang dalam Hukum Kepailitan." Jurnal Magister Hukum Udayana, vol. 3, no. 1 (2014): 8

15 Kusumayanti, Made Martarina, "Implementasi Perlindungan Hukum Bagi Franchisor dalam Perjanjian Waralaba Pada Edam Burger di Denpasar." Jurnal Kertha Semaya, vol. 4, no. 3 (2016): 8 
Pihak kedua selaku penerima waralaba harus menjalankan segala kewajiban dalam pelaksanaan Perjanjian yang berlaku, pelanggaran yang dapat terjadi oleh Pihak kedua. Apabila Pihak kedua tidak melaksanakan kewajiban seperti tidak mengikuti ketetapan yang ada didalam Perjanjian Teh Poci dari segi hak dan kewajiban, pembiayaan, pelaksanaan prosedur lokasi waralaba, yang ada didalam Perjanjian Teh Poci dan dengan terjadinya suatu wanprestasi pada Perjanjian yang telah disepakati maka perjanjian yang telah disepakati dapat berakhir.

Upaya Penyelesaian Perselisihan Wanprestasi yang ada pada Perjanjian Waralaba Es The Poci di Kota Denpasar yang ada dalam perjanjian, menyatakan bila terjadi sengketa antara pihak - pihak maka perjanjian tersebut akan diselesaikan dengan cara musyawarah dan mufakat, apabila sudah dilakukan secara musyawarah namun tidak dapat menemukan kesepakatan yang diinginkan maka para pihak akan menggunakan penyelesaian dengan cara hukum, sesuai dengan hukum yang berlaku dan para pihak sepakat memilih meyelesaikan di Pengadilan Negeri Denpasar.

\section{Kesimpulan}

Berdasarkan pembahasan dari masalah diatas maka dapat disimpulkan hal - hal sebagai berikut . Pada bentuk perjanjian waralaba Es Teh Poci dikota Denpasar merupakan bentuk perjanjian dibawah tangan, perjanjian di bawah tangan ialah perjanjian yang telah dilakukan pihak - pihak saja tanpa adanya campur tangan pejabat berwenang, namun demikian perjanjian dibawah tangan ini dimata hukum tetap dianggap sah serta tidak menghilangkan kewajiban serta dari kedua belah pihak, mengenai isi dari perjanjian Es Teh Poci, perjanjian Es Teh Poci memiliki segala ketentuan yang berlaku dalam menjalankan waralaba serta sanksi yang diberikan untuk para pihak yang tidak melakukan isi dari perjanjian, perjanjian tersebut menjadi suatu pedoman agar waralaba Es Teh Poci tetap dapat berjalan dengan baik didalam sistem hukum maupun segi penjualannya. Tentang akibat yang terjadi apabila pihak penerima waralaba melakukan wanprestasi didalam suatu Perjanjian waralaba Es Teh Poci di Kota Denpasar menjelaskan apabila pihak mitra melanggar isi dari perjanjian dari segi kewajiban dan hak, maka Perjanjian yang telah disepakati dapat berakhir. Dengan melepaskan ketentuan Pasal 1266 dan Pasal 1267 Kitab Undang-undang Hukum Perdata Pihak pemberi waralaba akan membatalkan perjanjian kerjasama dan meminta pihak penerima waralaba untuk menghentikan penjualan produk pihak pemberi waralaba.

\section{DAFTAR PUSTAKA}

Buku:

Amiruudin, dan Asikin, Zainal. Pengantar Metode Penelitian Hukum (Jakarta, Grafindo Persada, 2012).

HS, Salim. Hukum Perjanjian Teori dan Praktek Penyusunan Perjanjian (Jakarta, Sinar Grafika, 2008).

\section{Jurnal Ilmiah:}

Aliyah, Habibatul. "Analisis Dari Segi Hukum Terhadap Perjanjian Kemitraan Antara Usaha Mikro, Kecil, dan Menengah dengan Usaha Besar." Jurnal Kertha Semaya, Vol. 7, No. 3 (2019). 
Angelita, Zhannina Elrian. "Syarat - Syarat Pembentukan Perjanjian Waralaba Berdasarkan Peraturan Pemerintah Nomor 42 Tahun 2007 Tentang Waralaba." Jurnal Kertha Semaya, Vol. 3, No. 1 (2015).

Dewi, Putu Eka Trisna. "Implementasi Ketentuan Restrukturisasi Kredit Terhadap Debitur Wanprestasi Pada Kredit Perbankan." Jurnal Magister Hukum Udayana, Vo. 4, No. 2 (2015).

Handayani, Gusti Ayu Mirah. "Pelaksanaan Perjanjian Waralaba (Franchise) Kuch2hotahu Di Denpasar." Jurnal Kertha Semaya, Vo. 4, No. 3 (2015).

Kurniawan, Nyoman Samuel, Konsep Wanprestasi dalam Hukum Perjanjian dan Konsep Utang dalam Hukum Kepailitan." Jurnal Magister Hukum Udayana, Vol. 3, No. 1 (2014).

Kusumayanti, Made Martarina. "Implementasi Perlindungan Hukum Bagi Franchisor dalam Perjanjian Waralaba Pada Edam Burger di Denpasar." Jurnal Kertha Semaya, Vol. 4, No. 3 (2016).

Maharatih, Ni Wayan. "Studi Kritis Pengenaan Pajak Penghasilan Final Bagi Usaha Mikro Kecil Menengah." Jurnal Magister uUkum Udayana, Vol. 3, No. 1 (2019).

Paryani, Luh Suni Muci. "Wanprestasi dalam Pelaksanaan Perjanjian Waralaba Pada Lembaga Bimbingan Belajar Di Kota Denpasar." Jurnal Kertha Semaya, Vol. 3, No. 2 (2015).

Prasnowo, Aryo dan Badriah, Siti Malikhatun. "Implementasi Asas Keseimbangan Bagi Para Pihak Dalam Perjanjian Baku." Jurnal Magister Hukum Udayana, Vol. 8, No. 1 (2019).

Prawira, I Kadek Bagus Indra Dwi. "Perlindungan Hukum Terhadap Penerima Waralaba Yang Dapat Menimbulkan Praktek Monopoli." Jurnal Kertha Semaya, Vol. 3, No. 2 (2015).

Trisnadewi, Ida Ayu. "Kedudukan Hukum Para Pihak Dalam Perjanjian Waralaba di Indonesia." Jurnal Kertha Semaya, Vol. 2, No. 2 (2014).

Wisanjaya, I Gede Pasek Eka. “Tinjauan Yuridis Terhadap Klausula Dalam Perjanjian Waralaba Yang Dapat Menimbulkan Praktek Monopoli." Jurnal Kertha Semaya, Vol. 2, No. 6 (2014).

Website/ Internet:

https://www.scribd.com/doc/46240963/Asas-Kepastian-Hukum, diaskses pada 20 April 2020

\section{Peraturan perundang-undangan:}

Kitab Undang-Undang Hukum Perdata [Burgerlijk Wetboek]. Diterjemahkan oleh Subekti dan R. Tjitrosudibio. (Jakarta: Pradnya Paramita, 2008).

Peraturan Pemerintah Nomor 42 Tahun 2007 tentang Waralaba, Lembaran Negara Nomor 90 Tahun 2007, Tambahan Lembaran Negara Nomor 4742

Peraturan Menteri Perdagangan Republik Indonesia Nomor: 31/M-Dag/Per/8/2008 Tentang Penyelenggaraan Waralaba 